\title{
Predicting Volatility of Non-Performing Financing: Lessons from Indonesian Islamic Banking Industry
}

\author{
Faizul Mubarok ${ }^{1}$, Abdul Hamid ${ }^{2}$, M. Nur Rianto Al Arif ${ }^{3}$ \\ ${ }^{1,2,3}$ Universitas Islam Negeri Syarif Hidayatullah, Jakarta, Indonesia
}

Submitted: 13 February 2020, Accepted: 1 June 2020, Published: 5 June 2020

\begin{abstract}
Islamic banking financing is carried out into three categories, namely financing based on economic sectors, financing based on contracts, and financing based on types of use. The funding is faced with risks where the customer is unable to pay the loan. This study discusses the forecasting of Islamic banking problem financing in Indonesia using monthly data from 2003 to 2019. Prediction is made using the Autoregressive Conditional HeteroscedasticityGeneralized Autoregressive Conditional Heteroscedasticity (ARCH-GARCH) method. Forecasting from the results of this study shows that non-performing financing tends to decrease in Indonesia. Islamic banking has been able to manage problem financing well. Islamic banking financing should be focused on sectors that have low risk. The results of this study are undoubtedly useful for stakeholders to make policies to improve the quality of the funding.
\end{abstract}

Keywords: problem funding, volatility, ARCH-GARCH, Islamic banking 


\section{INTRODUCTION}

Banking as an intermediary institution that connects investors with those who need capital has a strategic role in the economy of a country(Levine, 1997). The development of the banking world, especially sharia banking will surely face challenges that must be responded appropriately (Budiono, 2017). One of the challenges is that there are changes in world economic conditions that can have an impact on bank financing(Supartoyo, Juanda, Firdaus, \& Effendi, 2018).

Islamic banking has gained traction in Indonesia, although the market share of Islamic banking is still small but the potential for growth continues to exist considering that Indonesia is the largest Muslim population in the world with various challenges(Rizvi, Narayan, Sakti, \& Syarifuddin, 2019). One of the challenges is that financing carried out by Islamic banking will be faced with conditions where the capital borrower is no longer able to pay bills. Nonperforming financing is defined as loans that are past due and cannot be repaid (Bolognesi, Stucchi, \& Miani, 2019). In Islamic banking, the problematic financing indicator is reflected in the problem financing with non-performing financing (NPF) indicator.

Research related to NPL/NPF has been conducted by Li and Zhang (2019) analyzing related to credit options and risks in Hong Kong. Zhang, Cai, Dickinson, and Kutan (2016) who examined the impact of NPLs on bank behavior in China. Tsai, Lu, and Hung (2016) investigated information in newspapers influencing credit risk in the United States. Gatfaoui (2017) investigates the relationship between credit and equity markets in the United States. Chang, Fuh, and Kao (2017); Cucinelli, Battista, Marchese, and Nieri (2018); Binici and Hutchison (2018); Ashour and Hao (2019) have improved the credit risk of companies in China and Western Europe.

Bian, Lin, and Liu (2018) study credit risk with property prices in China. Dendramis, Tzavalis, and Adraktas (2018) investigated economic recession, pressures on the financial sector and political instability are factors that influence problematic financing. Zamore, Beisland, and Mersland (2019) analyze the relationship between geographical diversification and credit risk in microfinance. Niu and Hua (2019) studied the optimal contract between managers and shareholders in the credit risk model and the impact of moral hazard on corporate credit risk. Aysan and Disli (2019) examine whether there is a causal relationship between loans and problem loans in Turkey.

From the existing research, most of them discuss the effect of problem financing and none have discussed the forecasting of problem financing. Therefore, this research was conducted to fill the gap of existing research. Thus, the purpose of this study is focused on discussing forecasting problematic financing. This research has important implications for risk 
managers and investors for optimal investment strategies (Troster, Tiwari, Shahbaz, \& Macedo, 2019). This research is also deemed necessary because it can contribute to stakeholders to determine policy alternatives.

\section{METHOD}

The data used in this study are secondary data from non-performing loans (NPF) of 14 sharia commercial banks and 20 sharia business units monthly from January 2003 to November 2019. Sharia banking sector data is random (random) and has high volatility, causing variable that is not constant. Volatility modeling is very important for risk management (Caporale \& Zekokh, 2019). Therefore, we need a model that can be used to predict problem financing with the condition that there is heteroscedasticity(McCauley, 2009).

The first step taken in this study is the identification of a model. The identification of this model is intended to find out what model will be used in research. So that data can be modeled with Autoregressive Moving Average (ARMA) or Autoregressive Integrated Moving Average (ARIMA), the thing that needs to be considered is that data must be stationary. If the stationary data is at a level, it can be modeled with ARMA. However, if the stationary data is at a difference, it can be modeled with ARIMA.

After getting data that has been stationary, then plots are made in the form of Autocorrelation (AC) and Partial Correlation (PAC) that are used to determine the order of the alleged model. Furthermore, after obtaining the alleged model, significance testing, residual testing and normality testing are carried out. Whereas in selecting the best model, it is chosen based on the value of the smallest Akaike Info Criterion (AIC) and the largest log likelihood.

The next step is to test heteroscedasticity in the residual model. If there is an element of heteroscedasticity, modeling is done using Autoregressive Conditional Heteroscedasticity $(\mathrm{ARCH})$ and Generalized Autoregressive Conditional Heteroscedasticity (GARCH). The equations that can be formed are as follows:

$\mathrm{Y}_{\mathrm{t}}=\emptyset_{1} \mathrm{Y}_{\mathrm{t}-1}+\emptyset_{2} \mathrm{Y}_{\mathrm{t}-2}+\cdots+\emptyset_{\mathrm{p}} \mathrm{Y}_{\mathrm{t}-\mathrm{p}}+\mathrm{e}_{\mathrm{t}}$; Model autoregressive orde $\mathrm{p}(\mathrm{AR}(\mathrm{p})) \ldots \ldots \ldots \ldots \ldots \ldots \ldots . . . . .1$

$\mathrm{Y}_{\mathrm{t}}=\mathrm{e}_{\mathrm{t}}-\theta_{1} \mathrm{e}_{\mathrm{t}-1}-\theta_{2} \mathrm{e}_{\mathrm{t}-2}-\cdots-\theta_{\mathrm{q}} \mathrm{e}_{\mathrm{t}-\mathrm{q}} ;$ Model moving averageorde $\mathrm{q}(\mathrm{MA}(\mathrm{q})) \ldots \ldots \ldots \ldots \ldots \ldots \ldots . .2$

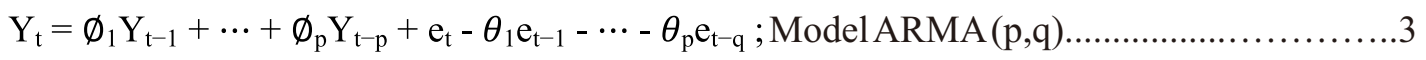

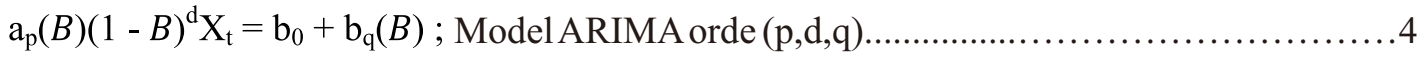

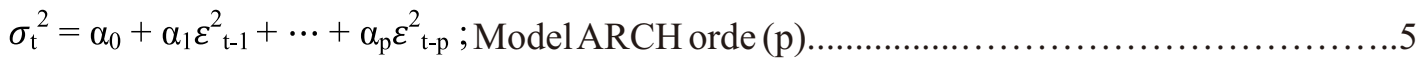

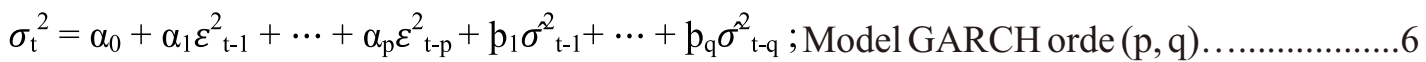


where

$$
\begin{array}{ll}
\emptyset_{1}, \emptyset_{2}, \ldots, \emptyset_{\mathrm{p}} & : \text { autoregressive parameter } \\
\mathrm{e}_{\mathrm{t}} & : \text { error at t-time } \\
\theta_{1}, \theta_{2}, \ldots, \theta_{\mathrm{q}} & : \text { moving average parameter } \\
\mathrm{e}_{\mathrm{t}-\mathrm{q}} & : \text { error at time } \mathrm{t}-\mathrm{q} \\
\mathrm{a}_{\mathrm{p}} B=1-\mathrm{a}_{1} B-\cdots-\mathrm{a}_{\mathrm{p}} B_{\mathrm{p}} & : \text { AR operator } \\
\mathrm{b}_{\mathrm{q}} B=1-\mathrm{b}_{1} B-\cdots-\mathrm{b}_{\mathrm{q}} B^{\mathrm{q}} & : \text { MA operator }
\end{array}
$$

\section{RESULTS AND DISCUSSION}

NPF of Islamic banking is one of the indicators of bank health regarding nonperforming financing consisting of substandard, doubtful, and loss. NPF values have fluctuating movements throughout the year of observation with high volatility. This high volatility is indicated by the phase where it has high fluctuations then followed by low and high fluctuations. However, based on observations it can be shown that the high volatility of the movement of the NPF value of Islamic banking has a downward trend. This shows that Islamic banking has been able to manage problem financing well.

Based on Figure 1, the average NPF value throughout the observation was 3.9 percent, with the highest value of 6.6 percent and the lowest value of 2.2 percent. Data distribution in general is normally distributed. This condition can be seen in the Jarque-Bera probability value which is above 5 percent while the symmetrical distribution indicated by the variable generally has a long tail on the right side (positive skewness). The kurtosis that appears, it turns out that the height measure of the data distribution is generally (leptokurtic). Then the results from standard deviations indicate the distribution of data in the sample by how close the individual data points are to an average of 0.96 percent.

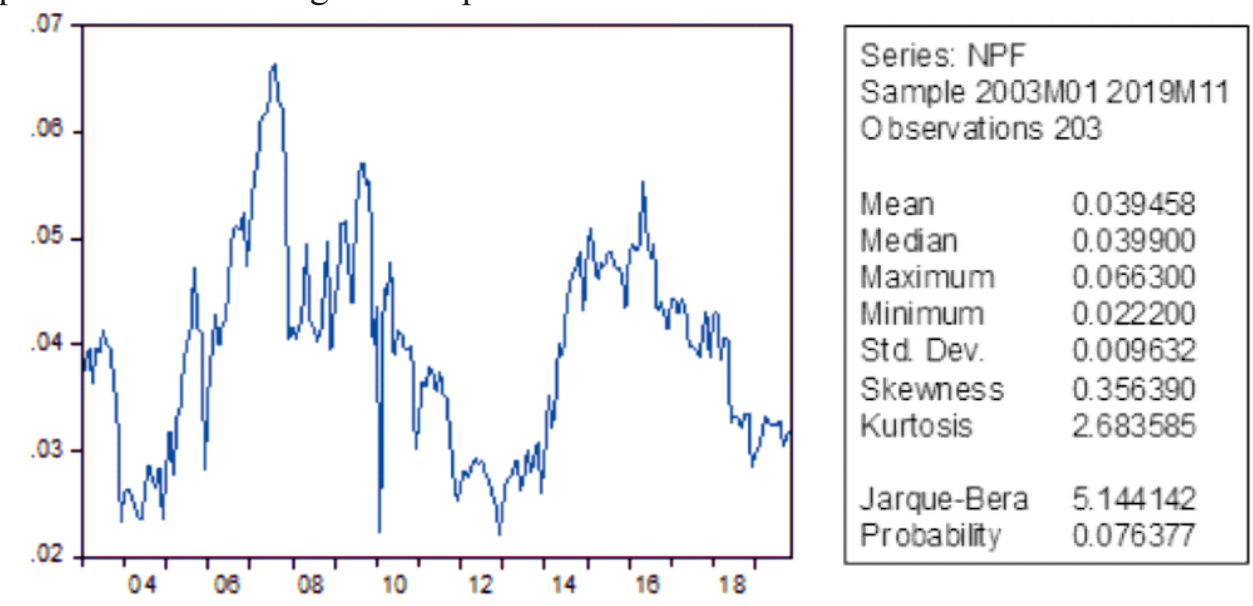

Figure 1. NPF Movements and Sharia Banking Descriptive Statistics 
The downward trend in non-performing financing in Islamic banking shows an improvement in the performance of Islamic banking in managing to finance disbursed to debtors. The decline in this trend is inseparable from the role of regulators in issuing policies that support economic growth so that financing disbursed always increases and nonperforming financing decreases. Islamic banking also avoids channeling financing to sectors that have high risk industries with high risks and are not in accordance with existing regulations in Islamic banking. This was done to create a sustainable financing climate.

Based on the results of the stationary data testing using the Augmented Dickey-Fuller (ADF) test, the NPF shows that the data is not stationary at the level (prob*0.136>0.05), but the data has been stationary at the difference (prob* $0,000<0.05$ ). As for using images there is a plot between observations with the time when the data level is not stationary and when the difference data is stationary by having a constant average and variance (Figure 2).
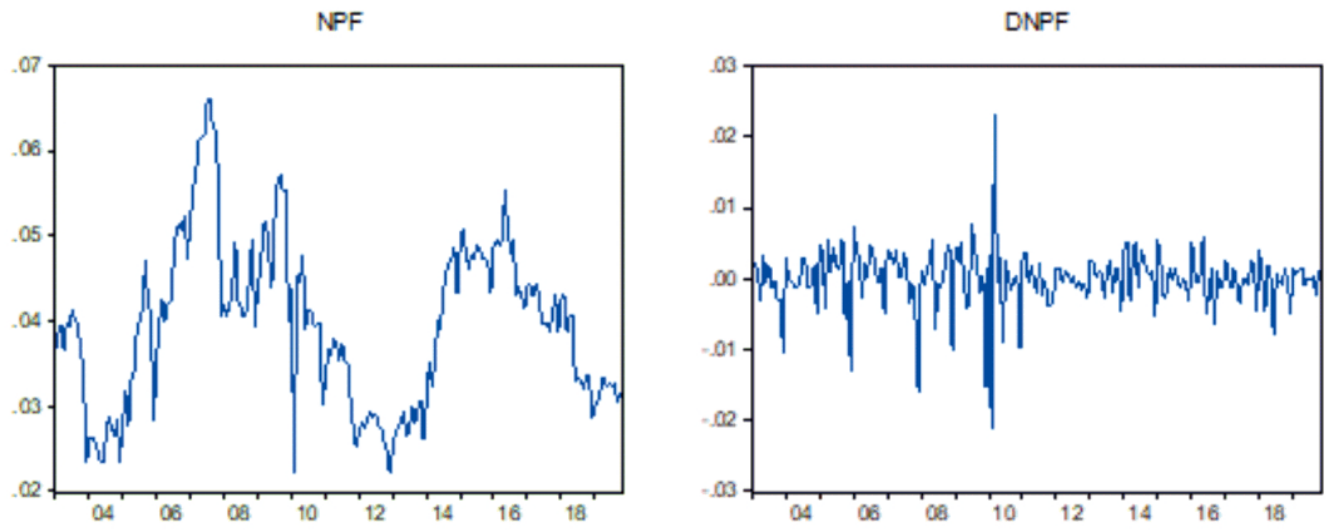

Figure 2. Data Stationarity Test Results at Level (a) and Difference (b)

Using data difference, then test the pattern of individual AC and PAC coefficients. From the test results, the ARIMA model can be determined by observing the AC and PAC patterns. The results of observing the pattern, showed that both the values of AC and PAC spikes were significant (AC and PAC $>-0.138$ and $+0.138<$ AC and PAC) contained in lag 1, lag 12 and lag 24 (Table 1).

Table 1. NPF Correlogram Difference Output

\begin{tabular}{cccccccccc}
\hline Lag & AC & PAC & Q-Stat & Prob & Lag & AC & PAC & Q-Stat & Prob \\
\hline 1 & -0.249 & -0.249 & 12.669 & 0.000 & 19 & -0.142 & -0.069 & 93.332 & 0.000 \\
2 & 0.114 & 0.056 & 15.341 & 0.000 & 20 & -0.008 & -0.077 & 93.348 & 0.000 \\
3 & -0.141 & -0.107 & 19.449 & 0.000 & 21 & -0.042 & -0.059 & 93.755 & 0.000 \\
4 & 0.026 & -0.040 & 19.588 & 0.001 & 22 & -0.009 & -0.027 & 93.774 & 0.000 \\
5 & -0.150 & -0.147 & 24.292 & 0.000 & 23 & -0.043 & 0.028 & 94.209 & 0.000
\end{tabular}




$\begin{array}{cccccccccc}6 & 0.232 & 0.168 & 35.598 & 0.000 & 24 & 0.387 & 0.280 & 128.86 & 0.000 \\ 7 & -0.132 & -0.037 & 39.280 & 0.000 & 25 & -0.094 & 0.084 & 130.91 & 0.000 \\ 8 & -0.002 & -0.102 & 39.281 & 0.000 & 26 & 0.078 & 0.068 & 132.33 & 0.000 \\ 9 & -0.009 & 0.017 & 39.296 & 0.000 & 27 & -0.056 & 0.043 & 133.06 & 0.000 \\ 10 & -0.006 & -0.019 & 39.303 & 0.000 & 28 & -0.076 & -0.054 & 134.44 & 0.000 \\ 11 & -0.126 & -0.121 & 42.738 & 0.000 & 29 & -0.150 & -0.108 & 139.82 & 0.000 \\ 12 & 0.347 & 0.283 & 68.847 & 0.000 & 30 & 0.170 & -0.056 & 146.75 & 0.000 \\ 13 & -0.121 & 0.032 & 72.040 & 0.000 & 31 & -0.158 & -0.108 & 152.77 & 0.000 \\ 14 & 0.001 & -0.087 & 72.040 & 0.000 & 32 & -0.006 & -0.109 & 152.78 & 0.000 \\ 15 & -0.075 & -0.048 & 73.294 & 0.000 & 33 & 0.028 & 0.008 & 152.96 & 0.000 \\ 16 & -0.064 & -0.096 & 74.208 & 0.000 & 34 & -0.075 & -0.068 & 154.33 & 0.000 \\ 17 & -0.115 & -0.081 & 77.170 & 0.000 & 35 & -0.102 & -0.147 & 156.91 & 0.000 \\ 18 & 0.228 & 0.089 & 88.766 & 0.000 & 36 & 0.258 & 0.015 & 173.44 & 0.000\end{array}$

From the correlogram results that have been obtained, then an alternative ARIMA model will be conducted based on significant spikes. From the alternative ARIMA models tested aim to choose the best model where the difference lies in the error variant. The alternative ARIMA models are as follows:

$\mathrm{D}(\mathrm{NPF})=\mathrm{c}+\mathrm{AR}(1)+\mathrm{AR}(12)+\mathrm{AR}(24)$

$\mathrm{D}(\mathrm{NPF})=\mathrm{c}+\mathrm{MA}(1)+\mathrm{MA}(12)+\mathrm{MA}(24)$

$\mathrm{D}(\mathrm{NPF})=\mathrm{c}+\mathrm{AR}(1)+\mathrm{AR}(12)+\mathrm{AR}(24)+\mathrm{MA}(3)+\mathrm{MA}(12)+\mathrm{MA}(24)$

The selection of the best ARIMA models includes the ARCH model, the GARCH model, the ARCH in Mean (ARCH-M) model, the ARCH Threshold model (TARCH), and the Expansion GARCH (EGARCH) model. Based on the results of the processing that has been done, it can be concluded that the best model is the TARCH model based on the largest log likelihood value and the smallest AIC (Table2).

Furthermore, after getting the best model, ARCH-LM will be tested for the best model. Based on the results of the processing that has been done, it can be seen that the value of Prob. Chi-Square (1) is 0.5074 , where the value is greater than the value of 0.05 so it can be concluded that the estimated TARCH model is free from the ARCH effect (Table 3 ). 
Table 2. Summary of Indicators for Selecting the Best Model

\begin{tabular}{|c|c|c|c|c|c|c|c|c|}
\hline \multirow{2}{*}{ Model } & \multicolumn{6}{|c|}{ Significance Parameters $\quad(\alpha=5 \%)$} & \multirow{2}{*}{$\begin{array}{c}\text { Log } \\
\text { Likelihood }\end{array}$} & \multirow{2}{*}{ AIC } \\
\hline & AR(1) & $\mathrm{AR}(12)$ & AR(24) & MA(1) & MA(12) & MA(24) & & \\
\hline $\mathrm{ARCH}(1)$ & $\mathrm{v}$ & $\mathrm{x}$ & $\mathrm{v}$ & $\mathrm{x}$ & $\mathrm{x}$ & $\mathrm{v}$ & 772.36 & -8.58 \\
\hline $\operatorname{GARCH}(1,1)$ & $\mathrm{x}$ & $\mathrm{v}$ & $\mathrm{v}$ & $\mathrm{v}$ & $\mathrm{v}$ & $\mathrm{v}$ & 795.31 & -8.82 \\
\hline $\mathrm{ARCH}-\mathrm{M}$ & $\mathrm{v}$ & $\mathrm{x}$ & $\mathrm{v}$ & $\mathrm{x}$ & $\mathrm{v}$ & $\mathrm{v}$ & 775.46 & -8.6 \\
\hline TARCH & $\mathrm{x}$ & $\mathrm{x}$ & $\mathrm{v}$ & $\mathrm{v}$ & $\mathrm{x}$ & $\mathrm{v}$ & 796.64 & -8.83 \\
\hline EGARCH & $\mathrm{v}$ & $\mathrm{x}$ & $\mathrm{v}$ & $\mathrm{v}$ & $\mathrm{x}$ & $\mathrm{v}$ & 787.71 & -8.73 \\
\hline
\end{tabular}

Table 3. ARCH Effect Testing Results for the TARCH Model

\begin{tabular}{llll}
\hline \multicolumn{4}{l}{ Heteroscedasticity Test: ARCH } \\
\\
\hline F-statistic & 0.435639 & Prob. F(1,175) & 0.5101 \\
Obs*R-squared & 0.439523 & Prob. Chi-Square(1) & 0.5074 \\
\hline
\end{tabular}

After testing, the ARCH-LM can then be forecasted. Forecasting results obtained from the value of Root Mean Square Error (RMSEA), Mean Absolute Error (MAE) and Mean Absolute Percent Error (MAPE) which is useful to find out how much error from forecasting is done. The value of each indicator can be known the average square root of forecasting error obtained by 0.009 (RMSE), the average absolute error obtained by 0.008 (MAE) and the average absolute percentage of error obtained by 22.13 (MAPE). From the indicator MAPE values generally obtain a small value so that the forecast results can be concluded close to the actual value (Figure 3).

This study predicts the movement of NPF of Islamic banking over the next 22 months. From the results of forecasting that have been done, it can be seen that the tendency of NPF has decreased every month with an average decrease of 6.92 percent. Forecasting is done in early 2020, which has increased from the actual data that has been obtained. November 2019 initially NPF value of 3.18 percent to 4.09 percent in January 2020. Then in the following month NPF of Islamic banking decreased with until the end of forecasting, namely December 2021. Forecasting the movement of the NPF which tends to fall will have an impact on the increase of financing carried out by Islamic banking, especially to sectors that have low risk(Chen \& Lin, 2016). The characteristics of companies which include size, sector and legal status are common obstacles faced by banks in providing financing(Mertzanis, 2016). 


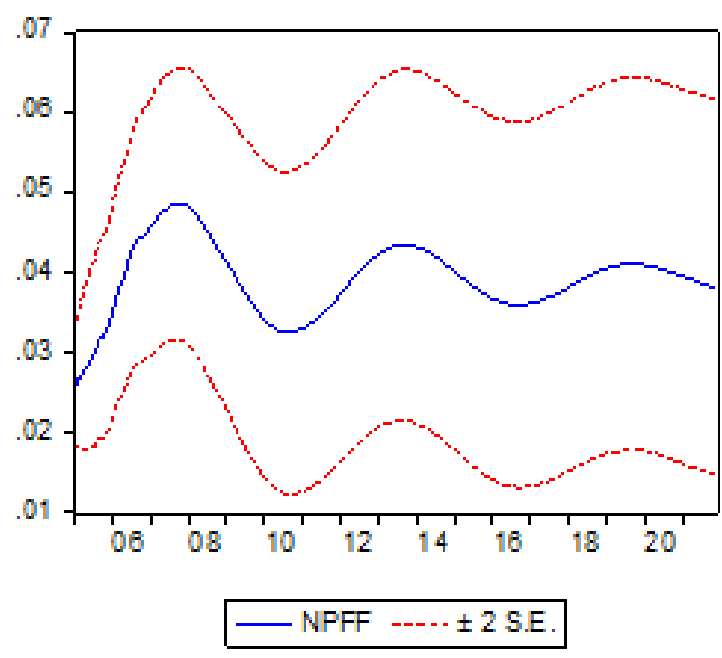

a

\section{Fore cast: NPFF \\ Actual: NPF}

Fore cast sample: 2003M01 2021M12

Adjusted sample: 2005M01 2021M12

Included observations: 179

Root Mean Squared Eror

Mean Absolute Error

Mean Abs. Percent Error

Theil In equality Coefficient

Bias Proportion

Variance Proportion

Covariance Proportion
0.009679

0.008389

22.13017

0.119554

0.022571

0.235197

0.742232

Figure 3. Dynamic Forecast

NPF forecasting of sharia banking, which tends to decline is inseparable from the efforts of sharia banks to implement rescheduling, restructuring, and reconditioning programs (Ashraf, Zheng, Jiang, \& Qian, 2020). On the other hand, Islamic banking has also made intensive underwriting and monitoring processes for financing customers and has been more careful in expanding financing (Hassan, Khan, \& Paltrinieri, 2019). One of the efforts is by entering into financing with segments, sectors, and customers with a low level of risk(Trabelsi \& Naifar, 2017). The results of this study indicate that the NPF value has decreased following the sharia banking statistics report (2019). Most of the financing uses the Musharaka and Mudharabah contracts where the contract is at low risk with the profit-sharing scheme.

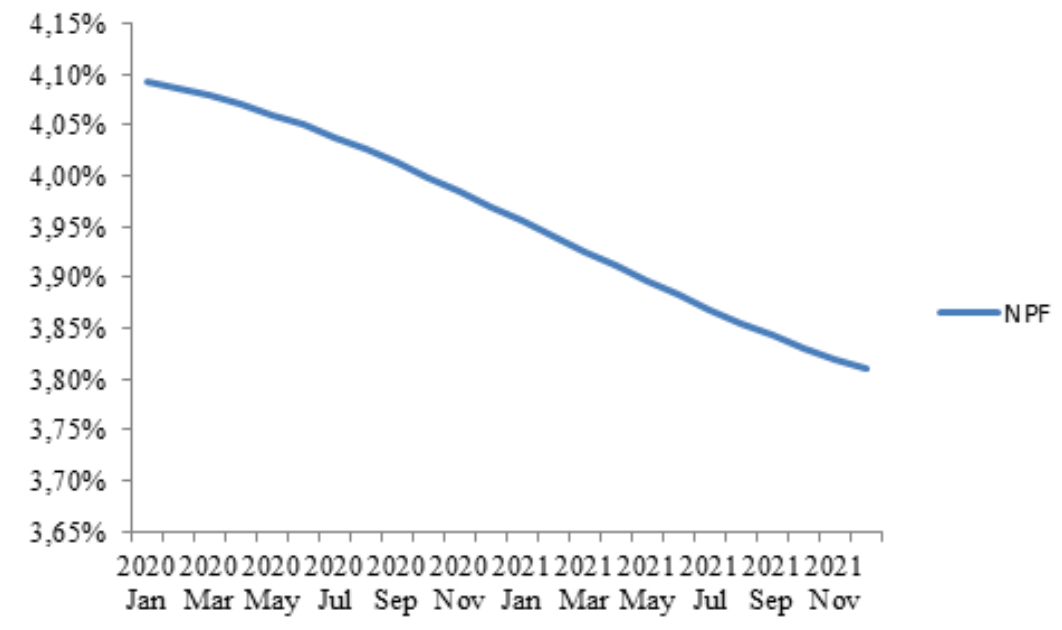

Figure 4. NPF Value Forecasting of Islamic Banking 
Islamic banking also needs to improve the capability of human resources to strengthen the analysis, risk mitigation, and management relationships (Azmat, Skully, \& Brown, 2014). So that Islamic banking as an intermediary institution needs to carry out its functions effectively and efficiently (Rahman, Sulaiman, \& Said, 2018). This can be done by paying close attention to the conditions of the prospective financing customers so that there are no problematic financing in the future (Rahman, Zheng, Ashraf, \& Rahman, 2018). In addition, an effective monetary policy in considering the nature of Islamic banking is very much needed to manage the supply of credit in the economy (Rashid, Hassan, \& Shah, 2020). The quality of financing and the capital ratio have an important role in financing risk(Misman, Bhatti, Lou, Samsudin, \& Rahman, 2015).

Table 4. Actual Value and Forecasting Value

\begin{tabular}{clllllllc}
\hline Year & Month & Actual & Year & Month & Forecasting & Year & Month & Forecasting \\
\hline Jan & $2.99 \%$ & 2019 & Dec & $4.10 \%$ & 2020 & Nov & $3.98 \%$ \\
Feb & $3.05 \%$ & & Jan & $4.09 \%$ & & Dec & $3.97 \%$ \\
Mar & $3.18 \%$ & Feb & $4.09 \%$ & Jan & $3.96 \%$ \\
Apr & $3.34 \%$ & Mar & $4.08 \%$ & Feb & $3.94 \%$ \\
May & $3.25 \%$ & Apr & $4.07 \%$ & Mar & $3.93 \%$ \\
2019 & Jun & $3.26 \%$ & & May & $4.06 \%$ & Apr & $3.91 \%$ \\
Jul & $3.24 \%$ & & Jun & $4.05 \%$ & 2021 & May & $3.90 \%$ \\
Aug & $3.28 \%$ & & Jul & $4.04 \%$ & & Jun & $3.88 \%$ \\
Sep & $3.05 \%$ & Aug & $4.03 \%$ & & Jul & $3.87 \%$ \\
Oct & $3.15 \%$ & Sep & $4.01 \%$ & & Aug & $3.86 \%$ \\
Nov & $3.18 \%$ & Oct & $4.00 \%$ & & Sep & $3.84 \%$ \\
\hline
\end{tabular}

The results of this study are also in line with research conducted by Kabir, Worthington, and Gupta (2015); Louhichi and Boujelbene (2016); Safiullah and Shamsuddin (2019) which shows that Islamic banking has significantly lower credit risk. The overall development of Islamic banking has no impact on credit constraints and has a positive impact on access to credit (Léon \& Weill, 2018). Financing quality with good financing potential is an attractive opportunity by utilizing diversification which is a very attractive opportunity for investors to invest (Bhuiyan, Rahman, Saiti, \& Ghani, 2019). Islamic banking needs to make the composition of the financing portfolio so that it can obtain the desired returns according to market risk(Narayan, Phan, Narayan, \& Bannigidadmath, 2017). 


\section{CONCLUSION}

The results of the study indicate that there are NPF values, there is an element of heteroscedasticity, which means that the residual variant of the data is not constant so that it is processed using the TARCH model to get a picture of the movement of NPF values in the coming months. The tendency of forecasting done using the TARCH model decreases. This is inseparable from the current ability of Islamic banking to manage financing risks by avoiding high risk sectors.

Overall, several policy implications that can be formulated include increasing the intensity of outreach related to the development and promotion of superior loan products to attract debtors, improve the quality of human resources, provide competitive interest rates and returns along with other facilities that can be obtained by borrowers, and service improvement and providing easy access to loan applications.

\section{BIBLIOGRAPHY}

Ashour, S., \& Hao, Q. (2019). Do Analysts Really Anchor? Evidence from Credit Risk and Suppressed Negative Information. Journal of Banking and Finance, 98, 183-197. https://doi.org/10.1016/j.jbankfin.2018.11.006

Ashraf, B. N., Zheng, C., Jiang, C., \& Qian, N. (2020). Capital Regulation, Deposit Insurance and Bank Risk: International Evidence from Normal and Crisis Periods. Research in International Business and Finance, 52,1-37. https://doi.org/10.1016/j.ribaf. 2020.101188

Aysan, A. F., \& Disli, M. (2019). Small Business Lending and Credit Risk : Granger Causality Evidence. Economic Modelling, 83, 245-255. https://doi.org/10.1016/ j.econmod. 2019.02 .014

Azmat, S., Skully, M., \& Brown, K. (2014). Credit Risk in Islamic Joint venture Bond. Journal of Economic Behavior and Organization, 103(7), 1-60. https://doi.org/10. 1016/j.jebo.2014.03.020

Bhuiyan, R. A., Rahman, M. P., Saiti, B., \& Ghani, G. B. M. (2019). Does the Malaysian Sovereign Sukuk Market offer Portfolio Diversification Opportunities for Global Fixed-Income Investors? Evidence from Wavelet Coherence and MultivariateGARCH Analyses. North American Journal of Economics and Finance, 47(7), 675-687.https://doi.org/10.1016/j.najef.2018.07.008

Bian, X., Lin, Z., \& Liu, Y. (2018). House Price, Loan-to-value Ratio and Credit Risk. Journal of Banking and Finance, 92, 1-12. https://doi.org/10.1016/j.jbankfin.2018.04.006 
Binici, M., \& Hutchison, M. (2018). Do Credit Rating Agencies Provide Valuable Information in Market Evaluation of Sovereign Default Risk? Journal of International Money and Finance, 85, 58-75.https://doi.org/10.1016/j.jimonfin.2018.04.001

Bolognesi, E., Stucchi, P., \& Miani, S. (2019). Are NPL-backed Securities an Investment Opportunity?. Quarterly Review of Economics and Finance (Article in Press), 1-33. https://doi.org/10.1016/j.qref.2019.10.007

Budiono, A. (2017). Penerapan Prinsip Syariah Pada Lembaga Keuangan Syariah. Law and Justice, 2(1), 54-65. https://doi.org/10.23917/laj.v2i1.4337

Caporale, G. M., \& Zekokh, T. (2019). Modelling Volatility of Cryptocurrencies Using Markov-Switching GARCH Models. Research in International Business and Finance, 48, 143-155.https://doi.org/10.1016/j.ribaf.2018.12.009

Chang, C., Fuh, C. D., \& Kao, C. L. M. (2017). Reading Between the Ratings: Modeling Residual Credit risk and Yield Overlap. Journal of Banking and Finance, 81, 114-135. https://doi.org/10.1016/j.jbankfin.2017.04.011

Chen, H. J., \& Lin, K. T. (2016). How Do Banks Make The Trade-offs Among Risks? The Role of Corporate Governance. Journal of Banking and Finance, 72(5), S39-S69. https://doi.org/10.1016/j.jbankfin.2016.05.010

Cucinelli, D., Battista, M. L. Di, Marchese, M., \& Nieri, L. (2018). Credit Risk in European Banks: The Bright Side of the Internal Ratings Based Approach. Journal of Banking and Finance, 93, 213-229. https://doi.org/10.1016/j.jbankfin.2018.06.014

Dendramis, Y., Tzavalis, E., \& Adraktas, G. (2018). Credit Risk Modelling under Recessionary and Financially Distressed Conditions. Journal of Banking and Finance, 91, 160-175. https://doi.org/10.1016/j.jbankfin.2017.03.020

Gatfaoui, H. (2017). Equity Market Information and Credit Risk Signaling: A Quantile Cointegrating Regression Approach. Economic Modelling, 64, 48-59. https://doi.org/10.1016/j.econmod.2017.03.012

Hassan, M. K., Khan, A., \& Paltrinieri, A. (2019). Liquidity risk, Credit Risk and Stability in Islamic and Conventional Banks. Research in International Business and Finance, 48, 17-31. https://doi.org/10.1016/j.ribaf.2018.10.006

Kabir, M. N., Worthington, A., \& Gupta, R. (2015). Comparative Credit Risk in Islamic and Conventional bank. Pacific Basin Finance Journal, 34, 327-353. https://doi.org/10.1016/j.pacfin.2015.06.001

Léon, F., \& Weill, L. (2018). Islamic Banking Development and Access to Credit. Pacific Basin Finance Journal, 52(7), 54-69. https://doi.org/10.1016/j.pacfin.2017.04.010

Levine, R. (1997). Financial Development and Economic Growth: Views and Agenda. Journal of Economic Literature, 35(2), 688-726. https://doi.org/10.1596/1813-9450-1678 
Li, G., \& Zhang, C. (2019). Counterparty Credit Risk and Derivatives Pricing. Journal of Financial Economics, 134(3), 647-668. https://doi.org/10.1016/j.jfineco.2019.04.011 Louhichi, A., \& Boujelbene, Y. (2016). Credit Risk, Managerial Behaviour and Macroeconomic Equilibrium within Dual Banking Systems: Interest-free vs. Interestbased Banking Industries. Research in International Business and Finance, 38, 104-121.https://doi.org/10.1016/j.ribaf.2016.03.014

McCauley, J. L. (2009). ARCH and GARCH models vs. martingale Volatility of Finance Market Returns. International Review of Financial Analysis, 18(4), 151-153. https://doi.org/10.1016/j.irfa.2009.05.002

Misman, F. N., Bhatti, I., Lou, W., Samsudin, S., \& Rahman, N. H. A. (2015). Islamic Banks Credit Risk: A Panel Study. Procedia Economics and Finance, 31, 75-82. https://doi.org/10.1016/S2212-5671(15)01133-8

Mertzanis, C. (2016). The Absorption of Financial Services in an Islamic Environment. Journal of Economic Behavior and Organization, 132, 216-236. https://doi.org/10.1016/j.jebo.2016.10.025

Narayan, P. K., Phan, D. H. B., Narayan, S., \& Bannigidadmath, D. (2017). Is There a Financial News Risk Premium in Islamic Stocks? Pacific Basin Finance Journal, 42, 158-170. https://doi.org/10.1016/j.pacfin.2017.02.008

Niu, H., \& Hua, W. (2019). An Endogenous Structural Credit Risk Model Incorporating with Moral Hazard and Rollover Risk. Economic Modelling, 78, 47-59. https://doi.org/10.1016/j.econmod.2018.09.012

Rahman, A. A., Sulaiman, A. A., \& Said, N. L. H. M. (2018). Does Financing Structure Affects Bank Liquidity Risk?. Pacific-Basin Finance Journal, 52, 26-39. https://doi.org/10.1016/j.pacfin.2017.04.004

Rahman, M. M., Zheng, C., Ashraf, B. N., \& Rahman, M. M. (2018). Capital Requirements, The Cost of Financial Intermediation and Bank Risk-taking: Empirical Evidence from Bangladesh. Research in International Business and Finance, 44, 488-503. https://doi.org/10.1016/j.ribaf.2017.07.119

Rashid, A., Hassan, M. K., \& Shah, M. A. R. (2020). On The Role of Islamic and Conventional Banks in the Monetary Policy Transmission in Malaysia: Do Size and Liquidity Matter? Research in International Business and Finance, 52, 101123. https://doi.org/10.1016/j.ribaf.2019.101123

Rizvi, S. A. R., Narayan, P. K., Sakti, A., \& Syarifuddin, F. (2019). Role of Islamic Banks in Indonesian Banking Industry: an Empirical Exploration. Pacific Basin Finance Journal (Article In Press), 1-10. https://doi.org/10.1016/j.pacfin.2019.02.002 
Safiullah, M., \& Shamsuddin, A. (2019). Risk-adjusted efficiency and corporate governance: Evidence from Islamic and conventional banks. Journal of Corporate Finance, 55, 105-140. https://doi.org/10.1016/j.jcorpfin.2018.08.009

Supartoyo, Y. H., Juanda, B., Firdaus, M., \& Effendi, J. (2018). Pengaruh Sektor Keuangan Bank Perkreditan Rakyat terhadap Perekonomian Regional Wilayah Sulawesi. Kajian Ekonomi \& Keuangan, 2(1), 14-38.

Trabelsi, N., \& Naifar, N. (2017). Are Islamic Stock Indexes Exposed to Systemic Risk? Multivariate GARCH Estimation of CoVaR. Research in International Business and Finance, 42(7), 727-744. https://doi.org/10.1016/j.ribaf.2017.07.013

Troster, V., Tiwari, A. K., Shahbaz, M., \& Macedo, D. N. (2019). Bitcoin Returns and Risk: A General GARCH and GAS Analysis. Finance Research Letters, 30, 187-193. https://doi.org/10.1016/j.frl.2018.09.014

Tsai, F. T., Lu, H. M., \& Hung, M. W. (2016). The Impact of News Articles and Corporate Disclosure on Credit Risk Valuation. Journal of Banking and Finance, 68, 100-116. https://doi.org/10.1016/j.jbankfin.2016.03.018

Zamore, S., Beisland, L. A., \& Mersland, R. (2019). Geographic Diversification and Credit Risk in Microfinance. Journal of Banking and Finance, 109. https://doi.org/10.1016/j.jbankfin.2019.105665

Zhang, D., Cai, J., Dickinson, D. G., \& Kutan, A. M. (2016). Non-performing Loans, Moral Hazard and Regulation of the Chinese Commercial Banking System. Journal of Banking and Finance, 63, 48-60. https://doi.org/10.1016/j.jbankfin.2015.11.010 